\title{
EMPLOYER BRAND IDENTITY OF SOFTWARE AND IT COMPANIES FROM CLUJ-NAPOCA AS REFLECTED IN THEIR WEBSITE CONTENT
}

\author{
Gyöngyvér Erika TŐKÉS ${ }^{1}$
}

\begin{abstract}
The paper highlights the characteristics of the employer brand identity of software and IT companies from Cluj-Napoca. The large IT companies from Cluj-Napoca are mainly Romanian delivery centers of international companies with outsourcing business strategy. Most of the locally based companies are medium or small sized IT companies working for both domestic and foreign markets. The majority of the Romanian delivery centers of international companies have complex employer brand identity which they use to attract the valuable workforce. Romanian medium sized companies from Cluj-Napoca present employer brand identity with medium complexity; however, their employer benefit lists are more modest than those of international companies. Romanian small sized companies from Cluj-Napoca have basic employer brand identity, merely formulated as answers to the request of the labor market.
\end{abstract}

Key words: Romanian software and IT industry, employer brand identity, company website, content analysis.

\section{Introduction}

In the knowledge-based economy, competition for the attention of different target groups has increased significantly, and companies are under pressure to attract and retain the attention of their target audience (Kapferer, 2008).

The main resource of the knowledge-based economy is high-level knowledge that can be converted into economic value. Companies in the knowledge-based industries are characterized by increased demand for talent (Manpower Group, 2016) and the appreciation of highly skilled workforce (Ambler \& Barrow, 1996). In a knowledge-based economy, competition for the talented workforce is as strong as the competition for customers (Berthon, Ewing, \& Hah, 2005). In order to attract the talented workforce and to retain the valuable employees, companies are forced to develop new management and communication strategies (Theurer, Tumasjan, Welpe, \& Lievens, 2018; Burmann, Riley, Halaszovich, \& Schade, 2017; Balmer, 2012).

\footnotetext{
${ }^{1}$ Sapientia Hungarian University of Transylvania, gyongyvert@ms.sapientia.ro
} 
In the struggle for talented workforce, building the employer brand is a strategic tool for managing the acquisition and retention of that workforce (Theurer et al., 2018; Ewing, Pitt, $\&$ de Bussy, 2002). A strong employer brand helps companies to gain a positive reputation as an employer (Ewing, Pitt, \& de Bussy, 2002). The need to consciously shape the relationship between the employer brand and employees is driven by the spread of digital media, which increases the expectation of target groups from companies to grow their information transfer and communication efficiency (Theurer et al., 2018).

In the process of employer brand management, defining brand identity can be considered as the starting point. Creating an incentive employer brand identity is the key to develop a strong brand (Aaker \& Joachimsthaler, 2009).

The purpose of the study is to analyze the employer brand identity of Cluj-Napoca companies operating in the software and IT services sector, in order to highlight good practices regarding recruitment. The paper is based on the content analysis of the data published on the websites of the investigated companies. The paper follows the characteristics of employer brand identity from the perspective of brand owners.

In Romania, the software and IT sector is one of the fastest developing economic sectors, but companies in the sector have so far been less visible. Software and IT companies provide more employer benefits than the general labor market in Romania, so these companies have a competitive advantage over other companies in recruiting talent. Currently, there is a growing shortage of competitive labor force in the labor market (Kerekes \& Molnár, 2017), therefore, attracting and retaining a talented workforce is an emergent challenge for software and IT companies, and one which necessitates higher visibility on the labor market.

The paper has the following structure: the first part of the paper defines the concepts of employer brand and brand identity; the second part describes the research methodology; the third part of the paper details the characteristics of the employer brand identity of software and IT companies in Cluj-Napoca, as well as the grouping of the investigated companies based on the complexity of their employer brand identity.

\section{Employer Brand}

The first definition of the concept of employer brand is related to Ambler and Barrow (1996). In their view, the employer brand is a set of functional, economic, and psychological/symbolic benefits that are associated with employment and are exclusively attributable to that company. An employer brand is a coherent framework for managing a company's workforce, which contributes to increased operational efficiency, effective recruitment, and retention and commitment of existing employees (Barrow \& Mosley, 2005).

The concept of employer brand was further developed by Backhaus and Tikoo (2004). According to Backhaus and Tikoo (2004), the employer brand emphasizes the uniqueness of the company's employment offer to motivate and retain existing employees and to attract future talent. The employer brand conveys an attractive representation of the company as an employer (Theurer et al., 2018). Backhaus and Tikoo (2004) and Barrow and Mosley (2005) used a similar approach in defining the employer brand, according to which the employer brand focuses on both existing and future workforces. Fernandez-Lores, Gavilan, Avello, \& Blasco (2016) have a similar point 
of view and believe that the employer brand communicates with both current and future employees.

In the knowledge-based economy, intangible assets play an important role in increasing the competitive advantage of companies (Fernandez-Lores et al., 2016; Mosley, 2007; Backhaus \& Tikoo, 2004). According to resource theory, having scarce and hard-to-replicate resources provides an opportunity for companies to outperform their competitors (Backhaus \& Tikoo, 2004). In this sense, having a highly talented workforce is an advantage for companies, as it is a resource that fulfills both the conditions of rarity and exclusivity.

Although companies in the knowledge-based economy employ fewer but very competitive employees, the nature and quality of the relationship between the company and its employees is more and more important (Ambler \& Barrow, 1996).

The purpose of the employer brand is to emphasize the benefits of the employer to current and future employees of the company. Employer brand management activities increase the chances of getting an excellent workforce and contribute to employee satisfaction and loyalty in the workplace (Fernandez-Lores et al., 2016).

Building a strong employer brand is very useful in a highly competitive labor market, especially in knowledge-based industries (Theurer et al., 2018; Ewing, Pitt, \& de Bussy, 2002; Schlager, Bodderas, Peter Maas, \& Cachelin, 2011). Employees of a company with an attractive employer brand are satisfied, highly identify with the goals and values of the company, and as a result, are willing to work hard for the goals of the company and to link their careers to the company in the long run (Backhaus \& Tikoo, 2004). A company with a strong employer brand will become well known on the labor market, thus attracting talented and competitive workforce more easily (Schlager et al., 2011).

Prior to the emergence of the knowledge-based economy, the long-term security of the workplace was the most important consideration for employees when selecting jobs. At present, companies cannot guarantee the long-term preservation of jobs, but young employees also do not want to stay with a company in the long run, so the composition of employer benefits has changed significantly. Companies offer functional benefits to employees such as acquiring competitive professional skills, good career opportunities, diverse job assignments and quality management. Employer loyalty is mainly driven by psychological benefits, which include personal and professional development opportunities, a sense of belonging, supporting individual goals, and opportunities to identify with the company (Fernandez-Lores et al., 2016).

\section{Brand Identity}

According to Aaker (2002), brand identity is the set of essential brand features that brand creators convey to their target audience. De Chernatony (2014) sees the central idea of the brand as the brand identity. According to Burmann et al. (2017), brand identity is the self-definition of the brand that reflects the creators' standpoint concerning the brand.

Brand identity is a multidimensional structure whose elements form a unit (Kapferer, 2008). In order for the stakeholders involved in brand management to be able to interpret the essence of the brand in a similar way, a clear and simple brand identity is needed (Kapferer, 2008; Esch, 2008). 
There are several conceptual models of brand identity (Aaker, 2002; Kapferer, 2008; de Chernatony, 2014; Urde, 2013), which primarily reflect the marketing approach.

In this paper the socio-scientific model of brand identity developed by Burmann et al. (2017) serves as a theoretical background for analyzing the constitution of employer brand identity. Burmann et al. (2017) have applied the findings of socio-scientific identity research to determine the construction of brand identity. They compared the brand identity to the human identity and the brand image to the social perception of the individual. Burmann et al. (2017) compare the characteristics of weak and strong human identity, subsequently deriving the most important elements of the brand identity construction from the characteristics resulting in a strong human identity.

On the basis of socio-scientific identity research Burmann et al. (2017) distinguish six constitutive elements which allow a comprehensive description of brand identity: offer, mission/vision, personality, values, competences and origin.

\section{Methodology}

The purpose of this paper is to analyze the characteristics of the employer brand identity of software and IT companies in Cluj-Napoca and to group the investigated companies based on the complexity of their employer brand identity. Research has shown that job seekers start by seeking information on potential jobs by visiting the websites of potential companies (Universum, 2017; Randstad, 2017). For this reason, the employer brand identity of software and IT companies in Cluj-Napoca was analyzed based on an analysis of the content posted on the corporate websites.

The research sample consisted of the websites of 110 software and IT companies from Cluj-Napoca. The method of data collection was combined content analysis (Neuendorf, 2002). The empirical data collection was conducted in September 2018.

The coding categories were developed in two steps. As a first step, quality content analysis was performed on 10 percent of the sample that resulted in an inductive coding category system. As a second step, the content analysis criteria system was determined in a deductive way based on literature. Finally, the two coding category systems were merged. The validity of the content analysis categories was tested by conducting a pilot research. During the pilot research, thirteen websites of software and IT companies from Cluj-Napoca were coded. The pilot research highlighted redundant coding categories that were eliminated in the research. The coding of the text corpus was assisted by the Atlas.ti quality data analysis program.

The reliability of the content analysis was tested by the Krippendorff Alpha reliability test. The analysis was performed on 10 percent of the sample. The value of the Krippendorff Alpha was 0.7672 , which exceeded the minimum value of 0.67 and is statistically acceptable (de Swert, 2011; Hayes \& Krippendorff, 2007). The value of the correlation between the coding of the two encoders was 0.771 . This value is very close to the 0.80 correlation coefficient, which can be considered statistically good.

The following operationalization scheme contains the variables that were found to be relevant to the content analysis of the employer brand identity of software and IT companies from Cluj-Napoca (Vans, 1991). 
Table 2

Operationalization of the employer brand identity of software and IT companies from Cluj-Napoca

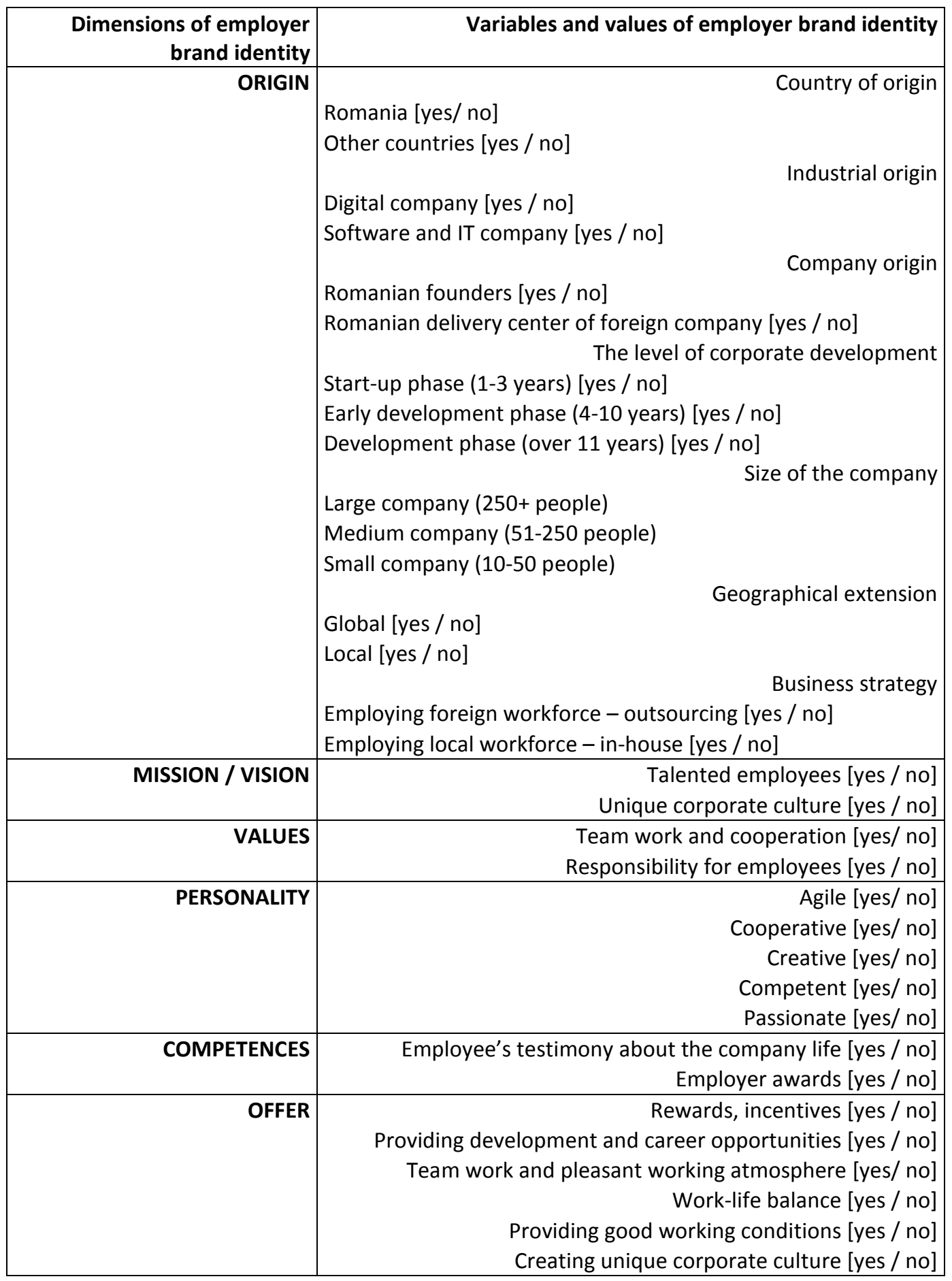




\section{Findings}

\subsection{The complexity of employer brand identity of software and IT companies in Cluj-Napoca}

The complexity of the employer brand identity was determined by the presence of the constitutive elements in the structure of the employer brand identity. The presence of the employer brand identity was indicated by the formulation of the mission and offer to employees. A job advertisement can be considered employer offer only if it includes employee benefits in addition to employer expectations.

Of the 110 software and IT companies in Cluj-Napoca, 12 did not formulate any messages to the employees. 98 Cluj-Napoca software and IT companies formulated messages to the employees, so they had employer brand identity.

Regarding the complexity of their employer brand identity, Cluj-Napoca software and IT companies can be characterized as follows:

Table 3

The complexity of the employer brand identity of software and IT companies in Cluj-Napoca (number of companies $/ \%, N=110$ )

\begin{tabular}{|r|r|r|}
\hline $\begin{array}{r}\text { Dimensions of the employer } \\
\text { brand identity }\end{array}$ & $\begin{array}{r}\text { Presence of the employer brand identity dimensions in the } \\
\text { constitution of the brand identity }\end{array}$ \\
\hline Origin & $110 / 100 \%$ \\
\hline Mission / vision & $80 / 72,7 \% \%$ \\
\hline Values & $64 / 58,2 \%$ \\
\hline Personality & $95 / 86,4 \%$ \\
\hline Competences & $24 / 21,8 \%$ \\
\hline Offer & $84 / 76,4 \%$ \\
\hline
\end{tabular}

Source: author's calculation

Data in Table 3 shows that three quarters of the software and IT companies in ClujNapoca have developed employer brand identity, that is, they have posted their mission and offer on their website regarding workforce. More than three-quarters of the companies surveyed reported personality traits that characterize their employer brand and are considered desirable qualities for current and future employees. Nearly twothirds of companies listed the values that characterize their relationship with the workforce. The inadequacy of the demonstration of competences indicates that this area is still new to the companies surveyed and that good practices regarding employees have not yet been developed.

\subsection{Grouping of the software and IT companies in Cluj-Napoca based on the complexity of their employer brand identity}

Companies were grouped based on the characteristics of their employer brand identity using the non-hierarchical cluster analysis method (K-Means Cluster) using the 
SPSS statistical program. The list of variables included in the grouping and the influencing power (significance) of the variables are given in Table 4.

Table 4

Variables affecting the cluster formation of software and IT companies from Cluj-Napoca according to the complexity of their employer brand identity and their significance in grouping $(N=98)$

\begin{tabular}{|c|c|}
\hline Variables & Level of significance* \\
\hline Business strategy: in-house (Yes/No) & 0,054 \\
\hline Business strategy: outsourcing (Yes/No) & 0,043 \\
\hline Establishment: Romanian founders (Yes/No) & 0,011 \\
\hline $\begin{array}{r}\text { Establishment: Romanian delivery center of an international } \\
\text { company (Yes/No) }\end{array}$ & 0,002 \\
\hline Date of establishment: year & 0,000 \\
\hline $\begin{array}{l}\text { The size of the company in 2016: (Small: } 1-50 \text { employees, Medium: } \\
51-250 \text { employees, Large: } \geq 251 \text { employees) }\end{array}$ & 0,035 \\
\hline Number of mission variables in the structure of brand identity (0-5) & 0,091 \\
\hline Number of value variables in the structure of brand identity (0-5) & 0,049 \\
\hline $\begin{array}{r}\text { Number of competency variables in the structure of brand identity } \\
(0-3)\end{array}$ & 0,000 \\
\hline Number of offer variables in the structure of brand identity (0-27) & 0,000 \\
\hline Personality: creative (Yes/No) & 0,000 \\
\hline Personality: disciplined (Yes/No) & 0,070 \\
\hline
\end{tabular}

*those variables are significant if $P$ value is smaller than 0,225

Source: authors' calculation

Variables with a significance level of 0.000 are the most important in defining company groups based on the complexity of the employer brand identity.

The characteristics of company groups formed on the basis of the complexity of their employer brand identity were mainly influenced by the richness of the employer offers and the presence of competencies justifying them, while among the characteristics of companies the most important were the conditions of establishment (Romanian founders or delivery centers of international companies), the level of development and the size of the companies. The classification of companies was also influenced by the brand personality traits. The business strategy of the company has also proved to be an important aspect, as the quality of the workforce is a source of competitiveness for outsourcing companies, so it is strategically important for them to establish an effective and positive emotional relationship with the workforce. An outsourcing business strategy can even lead to negative perceptions, and therefore, effective communication with the workforce by the companies involved is more important.

Table 5 summarizes the characteristics of the different company groups formed on the basis of the complexity of their employer brand identity. Based on the complexity of their employer brand identity, the software and IT companies from Cluj-Napoca formed three groups: with complex, medium and basic employer brand identity. 
Table 5

The characteristics of the groups of software and IT companies in Cluj-Napoca based on the complexity of their employer brand identity $(N=98)$

\begin{tabular}{|c|c|c|c|}
\hline $\begin{array}{r}\text { Variables of employer brand } \\
\text { identity }\end{array}$ & $\begin{array}{r}\text { Companies with } \\
\text { complex employer } \\
\text { brand identity }\end{array}$ & $\begin{array}{r}\text { Companies with } \\
\text { medium employer } \\
\text { brand identity }\end{array}$ & $\begin{array}{r}\text { Companies with } \\
\text { basic employer } \\
\text { brand identity }\end{array}$ \\
\hline $\begin{array}{r}\text { Business strategy: in-house } \\
\text { (Yes/No) }\end{array}$ & No & Yes & Yes \\
\hline $\begin{array}{r}\text { Business strategy: outsourcing } \\
\text { (Yes/No) }\end{array}$ & Yes & No & No \\
\hline $\begin{array}{r}\text { Establishment: Romanian } \\
\text { founders (Yes/No) }\end{array}$ & No & Yes & Yes \\
\hline $\begin{array}{r}\text { Establishment: Romanian delivery } \\
\text { center of an international } \\
\text { company (Yes/No) }\end{array}$ & Yes & No & No \\
\hline Date of establishment: year & 2008 & 1999 & 2009 \\
\hline $\begin{array}{r}\text { The size of the company in } 2016: \\
\text { (Small: } 1-50 \text { employees, Medium: } \\
51-250 \text { employees, Large: } \geq 251 \\
\text { employees) }\end{array}$ & $\begin{array}{r}\text { Medium } \\
51-250 \text { employees }\end{array}$ & $\begin{array}{r}\text { Medium } \\
51-250 \text { employees }\end{array}$ & $\begin{array}{r}\text { Small } \\
1-50 \text { employees }\end{array}$ \\
\hline $\begin{array}{l}\text { Number of mission variables in } \\
\text { the structure of brand identity (0- }\end{array}$ & $\begin{array}{r}\text { Talented } \\
\text { employee } \\
\text { centeredness } \\
\text { Unique company } \\
\text { culture }\end{array}$ & $\begin{array}{r}\text { Talented } \\
\text { employees }\end{array}$ & $\begin{array}{r}\text { Talented } \\
\text { employees }\end{array}$ \\
\hline $\begin{array}{l}\text { Number of value variables in the } \\
\text { structure of brand identity }(0-5)\end{array}$ & $\begin{array}{r}\text { Team work and } \\
\text { cooperation } \\
\text { Responsibility for } \\
\text { employees }\end{array}$ & $\begin{array}{r}\text { Team work and } \\
\text { cooperation }\end{array}$ & $\begin{array}{r}\text { Team work and } \\
\text { cooperation }\end{array}$ \\
\hline $\begin{array}{l}\text { Number of competency variables } \\
\text { in the structure of brand identity } \\
(0-3)\end{array}$ & $\begin{array}{r}\text { Employee's } \\
\text { testimony }\end{array}$ & No & No \\
\hline $\begin{array}{l}\text { Number of offer variables in the } \\
\text { structure of brand identity }(0-27)\end{array}$ & $\begin{array}{r}\text { On average } 12 \\
\text { offers } \\
\end{array}$ & $\begin{array}{r}\text { On average } 5 \\
\text { offers } \\
\end{array}$ & $\begin{array}{r}\text { On average } 3 \\
\text { offers } \\
\end{array}$ \\
\hline Personality: creative (Yes/No) & Yes & No & No \\
\hline Personality: disciplined (Yes/No) & Yes & Yes & Yes \\
\hline
\end{tabular}

Source: authors' calculation

Among the 98 Cluj-Napoca software and IT companies, the cluster analysis revealed three groups regarding the complexity of their employer brand identity: 30 companies had complex employer brand identity, 30 companies had medium brand identity and 38 companies had basic employer brand identity.

Among the companies with medium employer brand identity, many of them were small and medium sized Romanian companies that served the Romanian market and were established from the beginning as software and IT services companies. Medium employer brand identity companies emphasized the value of an excellent workforce, 
preferring teamwork as a form of working with employees. Companies with a medium employer brand identity were disciplined and passionate, but also their personality was characterized by agility and proactivity, which signaled their willingness to meet customer expectations. Companies with medium employer brand identities offered modest employer brand offerings, but enough functional and symbolic benefits to create the conditions for successful work. Functional benefits included providing a good salary, personal and professional development opportunities, a variety of professional tasks, and a comfortable work environment. Symbolic benefits include a friendly work atmosphere, strong team spirit and work-life balance. Companies with medium employer brand identity did not validate the credibility of their offerings while competencies were missing from the structure of their employer brand identity.

Companies with complex employer brand identity differed significantly in their origin from companies with medium employer brand identity. This group consisted mainly of medium-sized Romanian companies, as well as delivery centers of international companies with an outsourcing business strategy that served global and international markets. The mission of companies with complex employer brand identity was the same as that of the former group, but the values of the brand identity were complemented by the responsibility for employees, which highlighted the importance of recognizing quality collaboration with employees. Another important difference is the presence of the competence component of the employer brand identity, meaning that companies in this group presented employees' views about the company's internal life and the employment experience. The employer brand identity offer was markedly richer than that of companies with medium employer brand identity. The functional benefits were complemented by five interrelated elements that served to enhance the professional development and outstanding performance of the employees. These include the provision of training, support for the acquisition of professional licenses, internships, career opportunities and the creation of an empowering environment. The symbolic benefits were complemented by two elements, namely the development of a unique corporate culture and corporate social responsibility. A unique corporate culture enhances the psychological security of employees and contributes to a positive sense of professional identity through a sense of belonging. Corporate social responsibility enhances the company's external positive image, which also has a positive impact on the members' experience of belonging.

Companies with basic employer brand identity were small Romanian companies, mainly providing services to the Romanian market. In terms of mission and commitment, they were similar to those with medium employer brand identity, but were significantly lagging behind in employer offerings. In fact, they had only one employer offer, which was to provide comfortable working conditions. The personality of the employer brand identity had two qualities, namely agility, that is the ability of the company to adapt to customers' expectations, and being disciplined that is essential for performing service tasks.

The prevalence of the most popular employer offers in different groups of companies based on the complexity of their employer brand identity is shown in Table 6 . 
Table 6

Frequency of employers' offers within the groups of software and IT companies in Cluj-Napoca formed according to the complexity of their employer brand identity $(N=98)$

\begin{tabular}{|c|c|c|c|}
\hline $\begin{array}{r}\text { Variables of employer brand } \\
\text { identity }\end{array}$ & $\begin{array}{r}\text { Companies with } \\
\text { complex employer } \\
\text { brand identity }\end{array}$ & $\begin{array}{r}\text { Companies with } \\
\text { medium employer } \\
\text { brand identity }\end{array}$ & $\begin{array}{r}\text { Companies with } \\
\text { basic employer } \\
\text { brand identity }\end{array}$ \\
\hline Job diversity & $80 \%$ & $30 \%$ & $23,7 \%$ \\
\hline Work-life balance & $80 \%$ & $33,3 \%$ & $15,8 \%$ \\
\hline Friendly atmosphere & $73,3 \%$ & $33,3 \%$ & $26,3 \%$ \\
\hline Strong team spirit & $66,7 \%$ & $40 \%$ & $5,3 \%$ \\
\hline Good salary & $66,7 \%$ & $36,7 \%$ & $28,9 \%$ \\
\hline Unique company culture & $66,7 \%$ & $23,3 \%$ & $23,7 \%$ \\
\hline Good working conditions & $63,3 \%$ & $33,3 \%$ & $28,9 \%$ \\
\hline Trainings & $63,3 \%$ & $33,3 \%$ & $18,4 \%$ \\
\hline $\begin{array}{r}\text { Personal and professional } \\
\text { development opportunities }\end{array}$ & $60 \%$ & $30 \%$ & $26,3 \%$ \\
\hline Internship & $56,7 \%$ & $23,3 \%$ & $7,9 \%$ \\
\hline Support of exams and licenses & $56,7 \%$ & $23,3 \%$ & $5,3 \%$ \\
\hline Good social insurance & $56,7 \%$ & $10 \%$ & $10,5 \%$ \\
\hline
\end{tabular}

Source: authors' calculation

\section{Conclusions}

In the knowledge-based economy, a talented workforce is highly valued by service companies. Because marketability depends on how a company is able to turn knowledge into economic value and competition for highly skilled professionals almost surpasses the competition for clients.

Software and IT companies are welcomed by the Romanian workforce, but at the moment there are many more advertised jobs than there are young professionals in universities. Lack of manpower urges software and IT companies to find new tools and solutions in order to attract and retain a quality workforce.

A strategic management tool for recruiting and retaining excellent workforce is the employer brand creation. The purpose of the employer brand is to reach out to current and future employees of the company and to highlight the company's employment benefits. Creating an employer brand is much more effective than simply formulating job ads, because job ads only serve to describe functional and financial benefits, but the employer brand also has symbolic (emotional, self-expression) benefits that are the main attraction of workforce in the 21st century.

The purpose of the study was to analyze the employer brand identity of Cluj-based companies operating in the software and IT services sector, in order to highlight good practices that can be used in recruitment and retention of employees. The analysis was based on the content analysis of the data published on the websites of the investigated 
companies. The research followed the characteristics of employer brand identity from the perspective of brand creators.

The paper analyzed the employer brand identity of software and IT companies in ClujNapoca and grouped the investigated companies based on the complexity of their employer brand identity. Based on the characteristics of their employer brand identity, software and IT companies in Cluj-Napoca can be divided into three groups. Most international companies and traditional medium-sized Romanian companies have a complex employer brand identity. The majority of medium-sized companies in Romania are characterized by a medium employer brand identity, which is characterized by a lower level of employer offer. The employer brand identity of small Romanian companies is still evolving and, therefore, is on a basic level.

Both theoretically and methodologically, the paper provides novel results. The results of the research highlight the diversity of employment offers in the software and IT sector in Romania. At the same time, the paper presents an operationalization framework for the empirical measurement of employer brand identity, which is methodologically new, as existing scientific papers are largely conceptual and have not been empirically tested.

A limitation of the research is that it is a small sample exploratory study in which the employer brand identity was examined only from the companies' perspective. The study does not deal with the external perception of the employer brand, that is, the exploration of the employer brand image that would highlight the brand experience of job seekers and employees. The research could be continued in two directions: firstly, the characteristics of employer brand identity could be addressed across a representative Romanian sample and compared with international examples; on the other hand, the paper could be extended to the external perception of the employer's brand identity in order to reveal employer brand image among job seekers and employees.

\section{References}

Aaker, D. A. (2002). Building strong brands. London: Paperback.

Aaker, D. A., \& Joachimsthaler, E. (2009). Brand Leadership. London; Sydney; New York; Toronto: Pocket Books.

Ambler, T., \& Barrow, S. (1996). The Employer Brand. Journal of Brand Management, 4(3), 185-206.

Backhaus, T., \& Tikoo, S. (2004). Conceptualizing and researching employer branding. Career Development International, 9(4-5), 501-517.

Balmer, J. M. (2012). Strategic corporate brand alignment: Perspectives from identity based views of corporate brands. European Journal of Marketing, 46(7-8), 1064-1092.

Barrow, S., \& Mosley, R. (2005). The Employer Brand. Bridging the Best of Brand Management to People at Work. London: Wiley.

Berthon, P., Ewing, M., \& Hah, L. L. (2005). Captivating company: dimensions of attractiveness in employer branding. International Journal of Advertising, 24(2), 151172. 
Burmann, C., Riley, N.-M., Halaszovich, T., \& Schade, M. (2017). Identity-based Brand Management. Fundamentals - Strategy - Implementations - Controlling. Wiesbaden: Springer.

De Chernatony, L. (2014). From Brand Vision to Brand Evaluation. The Strategic Process of Growing and Strenghtening Brands. New York: Routledge.

De Swert, K. (2011). Calculating inter-coder reliability in media content analysis using Krippendorff's Alpha. University of Amsterdam. Retrieved from: https://www.polcomm.org/wp-content/uploads/ICR01022012.pdf.

Esch, F. R. (2008). Brand identity: the guiding star for successful brands. In B. H. Schmitt, \& D. L. Rogers (Eds.), Handbook on Brand and Experience Management (pp. 58-75). Cheltenham: PEFC.

Ewing, M., Pitt, L., \& De Bussy, N. (2002). Employment branding in the knowledge economy. International Journal of Advertising, 21(1), 3-22.

Fernandez-Lores, S., Gavilan, D., Avello, M., \& Blasco, F. (2016). Affective commitment to the employer brand: development and validation of a scale. Business Research Quaterly, 19(1), 40-54.

Hayes, A. F., \& Krippendorff, K. (2007). Answering the call for a standard reliability measure for coding data. Communication Methods and Measures, 1(1), 77-89.

Kapferer, J. N. (2008). The New Strategic Brand Management. Creating and Sustaining Brand Equity Long Term. London: Kogan Page.

Kerekes, K., \& Molnár, I. (2017). Causes and effects of the mismatch between demand and supply on the Romanian labor market. Forum on Economics and Business, 20(133), 34-57.

Manpower Group. (2016). 2016/2017 Talent Shortage Survey. Retrieved from: https://insights.manpowergroupsolutions.com/manpowergroup-2016-talentshortage-survey-results/.

Mosley, R. (2007). Customer experience, organizational culture and the employer brand. Journal of Brand Management, 15(2), 123-134.

Neuendorf, K. A. (2002). The Content Analysis Guidebook. Los Angeles, London: Sage.

Randstad. (2017). Randstad Employer Brand Research. Global report. Retrieved from: https://goo.gl/dizn1T.

Schlager, T., Bodderas, M., Peter Maas, P., \& Cachelin, J. L. (2011). The influence of the employer brand on employee attitudes relevant for service branding: an empirical investigation. Journal of Service Marketing, 25(7), 497-508.

Theurer, C., Tumasjan, A., Welpe, I. M., \& Lievens, F. (2018). Employer Branding. A Brand Equity-based Literature Review and Research Agenda. International Journal of Management Reviews, 20(1), 155-179.

Universum. (2017). The World Most Attractive Employers. Retrieved from: https://universumglobal.com/worlds-most-attractive-employers-2017/.

Urde, M. (2013). The corporate brand identity matrix. Journal of Brand Management, 20(9), 742-761.

Vans, D. A. (1991). Surveys in Social Research. London: UCL Press. 